\title{
Will Covid-19 Take the Air out of Silicon Valley?
}

\author{
Michael S. Dahl (Aalborg University) \\ Olav Sorenson (UCLA Anderson School of Management)
}

\author{
KEYWORDS: Entrepreneurship, Innovation, \\ Information Technology, Economic Development.
}

With the elections in the rearview mirror, attention has once again returned to the pandemic. We have been speculating as to what the long-lasting effects might be for entrepreneurs and for Silicon Valley.

In March, as a response to the rapid spread of COVID-19, organizations around the world ordered their employees to work from home. Though initiated as a temporary measure, many organizations and their employees have been pleasantly surprised by the detour ${ }^{[1]}$.

Employees have saved on time and the cost of commuting. Many have gained flexibility in when they work. Employers, meanwhile, have spent less on maintaining buildings and on providing services for their employees. Concerns that productivity would fall appear exaggerated ${ }^{[2] .}$

At some point, perhaps post-vaccine, many of these businesses will re-open their buildings. Others, however, may decide to retire the 9-to-5 office routine. Facebook, Google, and Twitter, have already announced that many of their employees will never return to the office full-time ${ }^{[3]}$.

For technology companies, this represents a U-turn. For the last three decades, both startups and technology giants in Silicon Valley (and elsewhere) have been encouraging employees to spend as much time as possible at the office. They have offered everything from free food and gyms to dog-walking services to keep them there. But if they can get the same amount of effort out of their employees at home, why spend money on all of these perks?

But the flip side of this question for employees is: If I can work for FaceBook or Google or anyone else from anywhere, why should I live in Silicon Valley?

\section{A victim of its own success}

Silicon Valley has become one of the richest regions in the world, as a continuous stream of high-tech startups over the past 50 years have brought new products and services to the world. It has been a Shangri-La for engineers and entrepreneurs. Pundits and policymakers alike have seen it as the archetype of an entrepreneurial ecosystem.

But Silicon Valley has also been a victim of its own success. Rents have risen. Though employers in the region pay a premium, home prices have still surged out of reach. Some high-tech employees have already decided to decamp ${ }^{[4]}$. If you're working from home, why share a cramped apartment in Palo Alto or San Francisco when you could buy your own place in Chicago or Colorado?

Some firms, such as Facebook, have threatened to cut the pay of those who move out of the area, which may keep some around ${ }^{[5]}$. But, based on our research and that of many others, we believe that the possibility of remote working should raise concerns about the future of Silicon Valley.

Much of the regions's success appears to come from the constant recombination of ideas and people and from the ease of founding a firm ${ }^{[6] . ~ T e c h ~ e m p l o y e e s ~}$ meet, quit their jobs, and start companies. Some succeed. Others fail but often try again after working for someone else for a while. All of this experimentation has been fueled by the world's densest concentration of venture capital.

But this recombination depends on proximity. People meet at coffee shops, bars, and soccer fields. Those initial accidental meetings lead to planned interactions. Some become friends. Friends become founding teams [7].

They also exchange valuable information through these connections. Complex information, in particular, such as the type of ideas underlying many of the latest 
innovations in software and hardware, only travels with extended interaction ${ }^{[8]}$. These ideas combine in novel ways to produce innovations.

When people come up with a new idea and decide to start a company to pursue it, they nearly always do so where they have been living ${ }^{[9]}$. That's where they have friends. That's where they have the connections that can help them to raise funds and to hire talent. As we pointed out in a previous EIX article, entrepreneurs have a home field advantage ${ }^{[10] \text {. }}$

\section{A fragile ecosystem}

If people work remotely - not just from home but from homes spread around the world - they will continue to meet others socially. They will still exchange ideas. They will still innovate. But if they found companies to pursue those ideas, they will operate in and enrich the places in which they live, not Silicon Valley.

That shift, moreover, could become a downward spiral. Entrepreneurial ecosystems can be fragile. They appear to require a constant stream of startups ${ }^{[11]}$. Startups provide inspiration for and serve as training grounds for future entrepreneurs. If the entrepreneurs spinning out of the current generation of Silicon Valley companies locate their own startups elsewhere, Silicon Valley might become more and more the province of technology titans. As the technologies underlying those firms age, the entire region's economy may suffer.

Although it's hard to imagine the decline of Silicon Valley right now, Detroit provides a cautionary tale. Detroit had been the Silicon Valley of an earlier era ${ }^{[12]}$. In the 1920s, it had been an incredibly entrepreneurial place, with thousands of entrepreneurs pursuing profit through automobile production or some related technology. The region became rich. But entrepreneurship - and some decades later the economy as a whole - ran out of gas as the automobile industry and employment in the region became concentrated in just a few firms.

On the positive side, a movement toward working from home might help to disperse better the benefits of the high-tech economy.

Unconstrained by the need to commute to a job, people usually choose to live in places that they grew up or where they have friends and relatives [9]. Talented engineers and entrepreneurs come from everywhere.
Most of the ones in Silicon Valley came from someplace else. If they can work from home, we would expect many of them to return to their hometowns or adopted hometowns, places that they lived before.

These hometown returnees, moreover, with one set of connections in Silicon Valley (or some other hub city) and another set in their home region, may be unusually well situated to become entrepreneurs. Their former city connections could help them to access venture capital, supply chains outside their regions, and distribution channels. But being outside of Silicon Valley also connects them to novel sources of information and to a different (and cheaper) talent base ${ }^{[10]}$.

Not only do these businesses create jobs themselves but also they could stimulate entire local economies. High-tech employees are paid well. They have money to spend on coffee shops, restaurants, and a variety of local services. In fact, most of the jobs created by venture capital investments appear to come not from the companies that they fund but from the spillovers of these investments into the local service economy ${ }^{[12]}$ The next wave of startups might then decentralize the economy and bring renewed prosperity to small- and medium-sized cities.

\section{References}

1. Moore, C. Working from Home Cost Employees Money But 35\% Want to Continue It Full-time. Fox Business, June 11, 2020

2. Bartik, A.W., Cullen, Z.B., Glaeser, E.L., Luca, M., and Stanton, C.T., What Jobs are Being Done at Home During the COVID-19 Crisis? Evidence from Firm-Level Surveys, NBER Working Paper \#27422

3. Hadden, J., Casado, L., Sonnemaker, T., Borden, T. 20 Major Companies That Have Announced Employees Can Work Remotely Long-Term. Business Insider, October 12, 2020

4. Costa, C. Facebook, Twitter, and VC Firms Consider Life Outside of Silicon Valley as They Shift to Remote Work. CNBC.com(http://cnbc.com/) , November 2, 2020

5. Bindley, K., Brown, E. Silicon Valley Pay Cuts Ignite Tech-Industry Covid-19 Tensions. Wall Street Journal(https://www.wsj.com/articles/silicon-valley-paycuts-ignite-tech-industry- 
covid-19-tensions-11602435601), October 11, 2020

6. Saxenian, A. Regional Advantage. Harvard University Press.

7. Ruef, M. The Entrepreneurial Group. Princeton University Press.

8. Sorenson, O., Rivkin, J., Fleming, L. Complexity, Networks, and Knowledge Flow. Research Policy, 35: 994-1017

9. Dahl, M.S., Sorenson, O. The Embedded Entrepreneur. European Management Review, 6: 172-181

10. Sorenson, O., Dahl, M.S. 'Home Field Advantage' Works in Business as well as Baseball, Entrepreneur \& Innovation Exchange, June 20, 2017

11. Sorenson, O. Regional Ecologies of Entrepreneurship. Journal of Economic Geography, 17: 959-974

12. Klepper, S. Disagreements, Spinoffs, and the Evolution of Detroit as the Capital of the US Automobile Industry. Management Science, 53: 616-631

13. Kwon, D, Sorenson, O. Silicon Valley Syndrome. SocArXiv. October 17, 2019. doi:10.31235/osf.io/zug2s. 